\title{
University Undergraduates' Propensity to Savings: A Case of Sri Lanka
}

\author{
B. L. J. S. Balasooriya ${ }^{1,2}$ \\ ${ }^{1}$ University of Colombo \\ ${ }^{2}$ Central Bank of Sri Lanka \\ Sri Lanka
}

\begin{abstract}
Savings is vital for any country to achieve a sustainable economic growth and development targets over the time as there is a close relation between savings and growth [2]. Most developing countries including Sri Lanka are facing budget deficit due to due to some reasons. Sri Lanka is currently encompassing small revenue both from domestic and foreign sources but government expenditure increasing which course continuous budget deficit as well as the deficit in Balance of Payment but cannot observe any push effects largely from national savings. Official data from Central Bank of Sri Lanka prove that the personal and household saving is the largest component of domestic saving in Sri Lanka for many decades. Therefore, this paper attempts to explore the undergraduates' propensity to savings in Sri Lanka to identify psychological and socio-economic perspectives behind the undergraduates' propensity to savings. The present study is based on a cross-sectional dataset collected by a questionnaire survey. A stratified sample of undergraduates was selected from the national universities in Sri Lanka to gather primary data. The main tool of the discrete data analysis was the Probit regression model apart from other standard statistical measurements. The data analysis reveals that a number of psychological and socio-economic variables decides undergraduates savings. Even though the results showed that that undergraduates' propensity to save on longterm perspectives are very low, short-term perspectives are high. Therefore, a number of psychological and socio-economic factors are making a significant influence on low propensity to savings, but there are some psychological and socio-economic variables that can improve savings on long-term perspectives.
\end{abstract}

\section{Introduction}

The importance and impact of savings have been recognised and widely accepted by many economists, and personal savings would play a significant role in the mobilisation of domestic resources in Sri Lanka too. Personal savings behaviour seems to be inculcated with culture, religion, family background [13], [22] in Sri Lanka too and uncertainty on the stability of economies.
However, precautionary motive plays a significant role in the determination of personal and household savings in any country. Sri Lankans precautionary motive exercise from the childhood and adulthood and how the families deal with unexpected emergencies or their prospects [15] are precious to their life.

The life-long asset development strategy for social development, and primarily on financial security and savings by Children's Development Accounts (CDAs) are helpful in accumulating savings in adulthood in the United States and some other countries [9]. Encourage children for asset accumulation and to prepare them to make wise financial decisions during their lifetime is necessary to learn lessons on financial education. Therefore, the CDAs are competent to inspire and assist in accumulating savings as expected [4]. However, insufficient saving facilities may create troubles at an individual; institutional; and national economy in many ways [10]. Therefore, improve the interaction of financial service, saving practices, and access to financial services is required to promote savings among citizen to achieve the expected growth targets.

The undergraduates are an educated group in the country who can perform a significant contribution to the economic development of the country through efficient decision making. Therefore, increase personal savings, cultivation of good saving practices should be planned in the early stages of the young generation. Because a strong savings habit [20] would establish sustainable savings in a country and it could lead to saving more at any cost [21] and a healthy level of savings has been widely accepted in the world. The savings habit seems to be inculcated by culture, religion, family background [13], [22] and practices of savings cushions village life from unpredictable emergencies. The experience of these practices from childhood to adulthood enriches and continues for years.

\section{Significance of the Study}

Sri Lanka a developing country which performs moderately during the past decades amidst many external shocks such as lower foreign reserves, ethnic 
conflict, policy failures, inherited economic turbulence, unbalance political and socio-cultural systems and their rigidities. In the meantime, low domestic savings is one of the main reasons that responsible for less investment in vital sectors since the independence. Sri Lanka could not reach the expected levels at operational perspectives yet because of less capital infusion which is not influenced by low savings, and this has been the major issue in Sri Lankan economy during past decades. The above also causes widening saving-investment gap annually, thus failing to fulfill public and private sector investment efficiently and effectively.

The country needs to review and take necessary action to enhance domestic saving to increase the investments, due to low domestic savings and low export earnings over the years. So, it is not just to increase savings but to establish an enduring saving culture which is very crucial for a country's development perspective [31]. Nevertheless, individuals cannot have to save unless they have the habit of savings, positive intentions to save, positive attitudes to saving and also simultaneously motivate themselves to save money rather than spending irrationally. Therefore, as pointed out by many economists, building domestic saving is the most useful and rationale for a developing country which would finance the government budget deficit to a certain extent.

It is essential to evaluate the role in promoting savings among undergraduates in Sri Lanka as successive governments have been allocating funds every year for universities, but the contribution from undergraduates seems to be minimal. The identification of saving propensity and financial education among undergraduates is important to check whether these guides an inculcating saving culture to sustain individual saving while building up the national saving. On the one hand, financial institutions have been investing a considerable amount of money to attract people to save money, but it is essential to re-evaluate the strategies and activities that need to encourage useful saving by the younger generation to have a concrete rationale throughout their lifetime.

\section{Literature on Savings}

Saving is treated as a behaviour under the influence of a complex array of potential influences, and a variety of predictors are used which operationalise demographic, economic and psychological factors [25]. Also, Saving is a behaviour, and it is affected by beliefs, attitudes and motivation, as well as self-determination and social norms [33]. Saving behaviour varies from person to person, culture to culture and year to year and not appear to be one universal and a constant equation which drives everyone to save in the same way under the same financial circumstances. Their propensity to save is influenced by different experiences and insights of people and changing people's experiences and understanding change the saving behaviour. However savings in South Asia are mainly determined by income, access to banking institutions, foreign savings rate and dependency rate, but the impact of the real interest rate on savings is minor and inconclusive [2] but an individual with financial literacy may not show expected behavior based on the literacy level due to other influences like cognitive and behavior that is biased to self-control problems, family, peers, economic and institutional conditions that may affect the financial habits and financial well-being.

Saving is refraining from consumption during one period targeting future consumption. From the psychological point of view, the saving behaviour is related to the fundamental question of how human deal with risk and uncertainty in the future to make sure of having sufficient assets for future consumption and saving behaviour implies the perception of future needs and an action [34], [15]. Also, Saving is referred to the process of not spending money for the present to use in future and saving behaviour is the combination of perceptions of future needs [32], [34].

Socio economic and demographic characteristics, expectations and motivations, access to resources, and the institutional environment are significantly associated with poor and low-income households' capability to save [18]. Also, willingness is not ability, but to practice as an ability which enables households to become willing and able to save.

Parental teachings on money management, mainly focused on the pocket allowance given for student, and those will help to increase the financial awareness, and the financial literacy of a child and also peer pressure appears to contribute to the higher number of savings and deposits during bank visit months but if families have no money to deposit, this could be a negative experience for the child [9]. However young people learn from direct and indirect interaction with peers; through discussions, rulemaking, reinforcement and modelling and influenced by peers inspiring that they can be easily pretentious by peer pressure when deriving to decisionmaking. Children save more money as they grow older and when they are older, recognise that saving is an effective form of money management [1]. Children are handling money, in particular, the savings is primarily influenced by their parents and Malaysian youth prefers the information on saving and investment by word of mouths from their parents and sibling.

Undergraduates are a vigilant and educated group and may be the future leaders of any country. Cultivating good savings practices among undergraduates are the key to success in the future. According to savings literature, individuals may have had many different saving motives such as precautionary motive, 
independence motive, enterprise motive, bequest motive and avarice motive, etc. A greater understanding of motivating factors could positively affect private saving motives [11] by giving them security in future and developing the intention to consume today. The other factor was that the most important motive of saving is to stay in control of finance. Conversely, the saving is a matter of practice, willingness, ability, and access to save, etc. and people should not have any saving without having any motivation and willingness [5].

Most of countries undergraduates' selection of a bank depends on many reasons such as location, parental advice, in close proximity, free service, service charges, interest rates, fast and efficient service, friendly staff, bank reputation, loan approval times, Internet banking, secure services, 24-hours ATM services, recommendation by parents, reliability, value-added services, accessibility, attractiveness etc. But most parents open savings accounts for their children at younger age to practice them the saving behaviour [23]. Further personal savings is an important variable influencing economic growth and commonly used in conventional economic theories. Demographic characteristics are also influenced savings to prepare for retirement, for a bequest, to fund education over the lifecycle in determining savings behaviour at different stages [14].

A savings-led microfinance model in Africa called Village Savings and Loans Associations for extremely poor, particularly women, the best approach is to begin by building their financial assets and skills through savings rather than debt which allows people to enter into the formal financial sector as savers rather than borrowers reducing the cost of funds bringing greater stability [17]. Self-control, future orientation, financial knowledge, autonomy, conscientiousness, and so forth focuses on the role of individuals, which controls by family income, and parents' education, employment, encouragement of having a savings habits, will continue young adults to be savers [30]. Institutions capacity to provide the access, information, incentives, facilitation, restrictions, decide youth is socialising into the adult economy by promoting youth saving and asset accumulation [30]. Also, parental teaching to save a substantial and significant positive effect on saving behaviour during childhood increases the likelihood that an individual will save more when they are adults [6] however women's propensity to save higher than that of males at least for this in semi-industrialized countries [12].

Lack of appropriate products, lack of incentive, lowincome level, high level of debt, low-interest rate, high inflation and others, are cause the poor saving culture in Ethiopia and is required inflation stabilization, forced saving, modernization of the accessibility of saving institution, income level stabilization, reviewing interest rate and others to establish good saving culture [16]. Free education from kindergarten to university education is one of the significant events in Sri Lanka but parents' education and parents' income have a strong effect on the education decision for their children [26] but not related to any cost involvement for such education discouraging student for having any savings for their education.

\section{Methodology}

The constructed econometric models to capture the variables using Theory of Planned Behaviour and Keynesian saving motives which would determine the savings propensity of undergraduates in Sri Lanka. The savings literature was used to recognise explanatory variables in econometric models which were used in the study. Motivation is the reason, or reasons one has for acting or behaving in a particular way and willingness is the quality or state of being prepared to do something; readiness [24].

The analysis was based on cross-sectional data gathered through a sample of undergraduates. Primary data covered the main areas such as demographic factors, psychological and social-economic factors of undergraduates which would impact on the determination of their savings. The sample constitutes 260 undergraduates who study in the University of Colombo. The demographic data shows that the sample comprises of $67 \%$ of 24 -year youths and $24 \%$ of 25 -year youths. The sample comprises of 65\% female, and 35\% male undergraduates who have accounts in banks. Most undergraduates receive both pocket money and scholarship allowances together with a monthly stipend either from internship or work and are positive about savings. The undergraduates might not have many income sources during the university course unless they are in the final year. They are mostly scholarship and loans recipients and also receive allowances from their parents.

Dependent variables Motivation (MO) and Willingness (WL) indicates the discrete values of motivation and willingness of undergraduates as (Very high $=6$, High=5, Medium=4, Low=3, Very Low=2, No effect=1)X = Vector of explanatory variables; it also includes self-control, satisfaction, future wealth, access to financial services, parent and relatives interaction, peer intervention, attitude, parent and teacher influence, sacrifice current consumption, future consumption, parent and others inputs and knowledge and guidance (SC, SA, FW, AFS, PRI, PI, AT, PTI, SCC, FC, POI, $\mathrm{KG})$.

The econometric models with the variables MO and WL as two dependent variables are as follows:

Motivation to save is a function of set variable, where; MO is the dependent variable (Motivation to save); 
$\beta=$ Vector of parameters to be estimated.

$\mathrm{MO}=f(\beta \mathrm{X}+\mu)$--------(1)

Econometric model 1:

$\mathrm{MO}_{i}=\mathrm{f}\left(\beta_{0}+\beta_{1} \mathrm{SC} i+\beta_{2} \mathrm{SA}_{\mathrm{i}}+\beta_{3} \mathrm{FW}_{\mathrm{i}}+\beta_{4} \mathrm{AFS}+\beta_{5} \mathrm{PRI}_{\mathrm{i}}+\beta_{6} \mathrm{PI}_{\mathrm{i}}\right.$

$\left.+\beta{ }_{7} \beta \mathrm{AT}_{\mathrm{i}+} \beta{ }_{8} \mathrm{PTI}+\beta_{9} \mathrm{SCC}_{\mathrm{i}}+\beta_{10} \mathrm{FC} \mathrm{i}+\beta_{11} \mathrm{POI}_{\mathrm{i}}+\beta_{12} \mathrm{KG}_{\mathrm{i}}+\mathrm{\varepsilon i}_{\mathrm{i}}\right)---(2)$

The Willingness to save is a function of set variable, where; WL is the dependent variable (Willingness to save);

$\mathrm{WL}=f(\beta \mathrm{X}+\mu)--------(3)$

Econometric Model 2:

$\mathrm{WL}_{\mathrm{i}}=\quad \mathrm{f}\left(\beta_{0}+\beta_{1} \mathrm{SC}_{\mathrm{i}}+\beta_{2} \mathrm{SA}_{\mathrm{i}}+\beta_{3} \mathrm{FW}_{\mathrm{i}}+\beta_{4} \mathrm{AFS}_{\mathrm{i}}+\beta_{5} \mathrm{PRI}_{\mathrm{i}}+\beta_{6} \mathrm{PI}_{\mathrm{i}}+\right.$ $\left.\beta_{7} \beta \mathrm{AT}_{\mathrm{i}+} \beta_{8} \mathrm{PTI}_{\mathrm{i}}+\beta_{9} \mathrm{SCC}_{\mathrm{i}}+\beta_{10} \mathrm{FC}_{\mathrm{i}}+\beta_{11} \mathrm{POI}_{\mathrm{i}}+\beta_{12} \mathrm{KG}_{\mathrm{i}}+\mu_{\mathrm{i}}\right)$--- (4)

The Hypotheses for the study are;

Hypothesis 1:

H0: The majority of undergraduates have no positive motivation to save.

H1: The majority of undergraduates have positive motivation to save.

Hypothesis 2:

H0: The majority of undergraduates have no positive willingness to save.

H1: The majority of undergraduates have positive willingness to save.

Hypothesis 3:

H0: The majority of undergraduates have no positive psychology and socio-economic factors to save

H1: The majority of undergraduates have positive psychology and socio-economic factors to saver results and conclusions Tables 1, and 2, show the results of econometric models under Ordered Probit analysis and Table 3 and 4 Wald test results. According Hypothesis 1 and 2 are rejected, and therefore 3 also rejected according to the results of Wald Test (see Table 3 and 4). The alternative hypotheses are accepted for econometric models, and subsequently, the majority of undergraduates have a positive motivation, willingness and psychology and socio-economic factors to save.

The psychological and socio-economic variables such as parent and relatives interaction, peer intervention, parent and teacher influence, parent and others inputs and knowledge and guidance are making a significant impact on both students' motivation to save and willingness to save (see Table 1 and 2). However, the variables - attitude, future consumption, future wealth, access to financial services, sacrifice current consumption, satisfaction, self-control which are anticipated as a long-lasting saving habit are not significant at 5 percent level means that no long-term objectives are involved in undergraduate savings.

The short-term oriented targets of undergraduate savings can be seen in comparison with the long-term oriented targets. The impact on short-term is due to 5 percent significant confidence level of parent and relative's interaction, peer intervention, parent and teacher influence, parents' influence on motivation and willingness.

Table 1. Confidence at 5 percent significantMotivation

Method: ML - Ordered Probit (Quadratic hill climbing)

\begin{tabular}{|l|l|l|l|l|}
\hline \multicolumn{5}{|l|}{ Dependent Variable: MOTIVATION } \\
\hline Variable & $\begin{array}{l}\text { Coeffici } \\
\text { ent }\end{array}$ & $\begin{array}{l}\text { Std. } \\
\text { Error }\end{array}$ & $\begin{array}{l}\text { Z- } \\
\text { Statistic }\end{array}$ & Prob. \\
\hline PRI & 0.843 & 0.132 & 6.381 & 0.000 \\
\hline PI & -0.387 & 0.075 & -5.156 & 0.000 \\
\hline PTI & -0.190 & 0.069 & -2.753 & 0.006 \\
\hline POI & 0.340 & 0.062 & 5.477 & 0.000 \\
\hline KG & 0.579 & 0.089 & 6.511 & 0.000 \\
\hline
\end{tabular}

Limit Points

\begin{tabular}{|l|l|l|l|l|}
\hline & $\begin{array}{l}\text { Coeffici } \\
\text { ent }\end{array}$ & $\begin{array}{l}\text { Std. } \\
\text { Error }\end{array}$ & $\begin{array}{l}\text { Z- } \\
\text { Statistic }\end{array}$ & Prob. \\
\hline LIMIT_2:C(6) & 1.042 & 0.438 & 2.380 & 0.017 \\
\hline LIMIT_3:C(7) & 2.954 & 0.384 & 7.699 & 0.000 \\
\hline LIMIT_4:C(8) & 4.074 & 0.415 & 9.808 & 0.000 \\
\hline LIMIT_5:C(9) & 5.607 & 0.456 & 12.306 & 0.000 \\
\hline LIMIT_6:C(10) & 7.157 & 0.504 & 14.200 & 0.000 \\
\hline
\end{tabular}

\begin{tabular}{|c|c|c|c|}
\hline Pseudo R-squared & 0.243 & $\begin{array}{ll}\begin{array}{l}\text { Akaike } \\
\text { criterion }\end{array} & \text { info } \\
\end{array}$ & 2.257 \\
\hline Schwarz criterion & 2.394 & Log likelihood & -281.10 \\
\hline $\begin{array}{l}\text { Hannan-Quinn } \\
\text { criter. }\end{array}$ & 2.312 & $\begin{array}{ll}\begin{array}{l}\text { Restr. } \\
\text { likelihood }\end{array} & \log \\
\end{array}$ & -371.49 \\
\hline LR statistic & 180.78 & $\begin{array}{l}\text { Avg. } \\
\text { likelihood }\end{array}$ & -1.090 \\
\hline Prob(LR statistic) & 0.000 & & \\
\hline
\end{tabular}

Note- parent and relatives interaction $=\mathrm{PRI}$, peer intervention $=\mathrm{PI}$, parent and teacher influence $=\mathrm{PTI}$, parent and others inputs =POI, knowledge and guidance $=\mathrm{KG}$

Table 2. Confidence at 5 percent significant Willingness

Method: ML - Ordered Probit (Quadratic hill climbing)

\begin{tabular}{|l|l|l|l|l|}
\hline \multicolumn{5}{|l|}{ Dependent Variable: WILLINGNESS } \\
\hline & $\begin{array}{l}\text { Coeffici } \\
\text { ent }\end{array}$ & $\begin{array}{l}\text { Std. } \\
\text { Error }\end{array}$ & $\begin{array}{l}\text { z- } \\
\text { Statistic }\end{array}$ & Prob. \\
\hline PRI & 0.884 & 0.137 & 6.460 & 0.000 \\
\hline PI & -0.371 & 0.077 & -4.848 & 0.000 \\
\hline PTI & -0.269 & 0.072 & -3.760 & 0.000 \\
\hline POI & 0.443 & 0.065 & 6.776 & 0.000 \\
\hline KG & 0.576 & 0.091 & 6.328 & 0.000 \\
\hline
\end{tabular}

Limit Points

\begin{tabular}{|l|l|l|l|l|}
\hline & $\begin{array}{l}\text { Coeffici } \\
\text { ent }\end{array}$ & $\begin{array}{l}\text { Std. } \\
\text { Error }\end{array}$ & $\begin{array}{l}\text { Z- } \\
\text { Statistic }\end{array}$ & Prob. \\
\hline LIMIT_2:C(7) & 1.706 & 0.399 & 4.277 & 0.000 \\
\hline LIMIT_3:C(8) & 2.982 & 0.389 & 7.671 & 0.000 \\
\hline LIMIT_4:C(9) & 4.193 & 0.426 & 9.850 & 0.000 \\
\hline LIMIT_5:C(10) & 6.030 & 0.480 & 12.556 & 0.000 \\
\hline LIMIT_6:C(11) & 7.905 & 0.549 & 14.410 & 0.000 \\
\hline
\end{tabular}

\begin{tabular}{|l|l|l|l|}
\hline Pseudo R-squared & 0.28 & $\begin{array}{l}\text { Akaike info } \\
\text { criterion }\end{array}$ & 2.03 \\
\hline Schwarz criterion & 2.17 & Log likelihood & -251.81 \\
\hline
\end{tabular}




\begin{tabular}{|l|l|ll|l|}
\hline $\begin{array}{l}\text { Hannan-Quinn } \\
\text { criter. }\end{array}$ & 2.08 & $\begin{array}{l}\text { Restr. } \\
\text { likelihood }\end{array}$ & log & -350.36 \\
\hline LR statistic & 197.11 & $\begin{array}{l}\text { Avg. } \\
\text { likelihood }\end{array}$ & $\log$ & -0.98 \\
\hline Prob(LR statistic) & 0.00 & & & \\
\hline
\end{tabular}

Note- parent and relatives interaction $=$ PRI, peer intervention $=\mathrm{PI}$, parent and teacher influence $=\mathrm{PTI}$, parent and others inputs $=\mathrm{POI}$ knowledge and guidance $=\mathrm{KG}$, self-control $=\mathrm{SC}$

Table 3. Wald Test Summery - Motivation

\begin{tabular}{lrrr}
\hline \hline Test Statistic & Value & df & Probability \\
\hline \hline F-statistic & 0.989 & $(7,241)$ & 0.440 \\
Chi-square & 6.926 & 7 & 0.437 \\
\hline \hline Null Hypothesis Summary: & & & \\
\hline \hline Normalized Restriction (=0) & & Value & Std. Err. \\
\hline \hline C(1)-SC & & 0.222 & 0.167 \\
C(2)-S & 0.113 & 0.097 \\
C(3)-FW & & 0.150 & 0.101 \\
C(4)-AFS & & -0.083 & 0.055 \\
C(7)-AT & -0.003 & 0.139 \\
C(9)-SCC & -0.057 & 0.122 \\
C(10)-FC & -0.099 & 0.143 \\
\hline \hline
\end{tabular}

Restrictions are linear in coefficients.

Table 4. Wald Test Summery -Willingness

\begin{tabular}{lrrr}
\hline \hline Test Statistic & Value & df & Probability \\
\hline \hline F-statistic & 1.949 & $(6,241)$ & 0.074 \\
Chi-square & 11.694 & 6 & 0.069 \\
\hline \hline Null Hypothesis Summary: & & & \\
\hline \hline Normalized Restriction (=0) & & Value & Std. Err. \\
\hline \hline \multirow{2}{*}{ C(1)-SC } & & 0.202 & 0.172 \\
C(2)-S & & 0.136 & 0.099 \\
C(3)-FW & 0.144 & 0.103 \\
C(7)-AT & & 0.024 & 0.142 \\
C(9)-SCC & & -0.141 & 0.125 \\
C(10)-FC & 0.146 & 0.147 \\
\hline \hline
\end{tabular}

Restrictions are linear in coefficients.
Table 5. Summary of Prediction Evaluation for Ordered Specification

\begin{tabular}{|l|l|l|l|}
\hline Equation & $\begin{array}{l}\text { Estimated Equation } \\
\text { of Ordered } \\
\text { Specification }\end{array}$ & $\begin{array}{l}\text { Constant } \\
\text { Probability } \\
\text { Spec /OLS }\end{array}$ & Total Gain \\
\hline 2 & 55.039 & 39.535 & 15.504 \\
\hline 4 & 60.078 & 43.798 & 16.279 \\
\hline
\end{tabular}

Table 6. Summary of gender-wise Ordered Probit 5 percent significant results for motivation and willingness

\begin{tabular}{|c|c|c|r|r|c|}
\hline & & \multicolumn{2}{l|}{ Female } & \multicolumn{2}{l|}{ Male } \\
\hline & & \multicolumn{1}{l|}{ Coefficient } & \multicolumn{1}{l|}{ Prob. } & \multicolumn{1}{l|}{ Coefficient } & \multicolumn{1}{l|}{ Prob. } \\
\hline & AFS & - & - & -0.263 & 0.014 \\
\hline Motivation & PRI & 0.728 & 0.000 & 0.921 & 0.000 \\
\hline & PI & -0.305 & 0.003 & -0.575 & 0.000 \\
\hline & PTI & - & - & -0.278 & 0.010 \\
\hline & POI & 0.261 & 0.001 & 0.636 & 0.000 \\
\hline & KG & 0.642 & 0.000 & 0.621 & 0.000 \\
\hline Willingness & PRI & 0.872 & 0.000 & 0.860 & 0.000 \\
\hline & PI & -0.346 & 0.001 & -0.429 & 0.000 \\
\hline & PTI & -0.245 & 0.017 & -0.351 & 0.001 \\
\hline & POI & 0.400 & 0.000 & 0.551 & 0.000 \\
\hline & KG & 0.555 & 0.000 & 0.661 & 0.000 \\
\hline & FW & 0.255 & 0.026 & - & - \\
\hline & AFS & - & - & -0.308 & 0.005 \\
\hline
\end{tabular}

Note- parent and relatives interaction $=$ PRI, peer intervention $=\mathrm{PI}$, parent and teacher influence $=\mathrm{PTI}$, parent and others inputs $=\mathrm{POI}$, knowledge and guidance $=\mathrm{KG}$, self-control $=\mathrm{SC}$, Satisfaction $=\mathrm{SA}$, Future Wealth $=\mathrm{FW}$, Access to Financial Services $=$ AFS, Attitude $=$ AT, Sacrifice Current Consumption $=$ SCC, Future Consumption $=\mathrm{FC}$

Table 7. Summary of Descriptive Statistics-Common Sample for motivation and willingness

\begin{tabular}{|l|l|l|l|l|}
\hline & & Mean & Std. Dev. & Probability \\
\hline motivation & SC & 3.916 & 0.811 & 0.000 \\
\hline & SA & 3.700 & 0.898 & 0.000 \\
\hline & FW & 4.144 & 1.005 & 0.005 \\
\hline & AFS & 4.274 & 1.896 & 0.000 \\
\hline & PRI & 3.627 & 1.062 & 0.009 \\
\hline & PI & 3.167 & 1.391 & 0.410 \\
\hline & AT & 4.103 & 0.925 & 0.000 \\
\hline willingness & PTI & 3.446 & 1.468 & 0.011 \\
\hline & SCC & 3.667 & 0.726 & 0.933 \\
\hline & FC & 4.012 & 0.897 & 0.000 \\
\hline & POI & 4.380 & 1.277 & 0.000 \\
\hline & KG & 4.101 & 0.989 & 0.009 \\
\hline
\end{tabular}

Note- parent and relatives interaction $=$ PRI, peer intervention $=$ PI, parent and teacher influence $=\mathrm{PTI}$, parent and others inputs $=\mathrm{POI}$, knowledge and guidance $=\mathrm{KG}$, self-control $=\mathrm{SC}$, Satisfaction $=\mathrm{SA}$, Future Wealth $=\mathrm{FW}$, Access to Financial Services $=$ AFS, Attitude $=$ AT, Sacrifice Current Consumption $=$ SCC Future Consumption $=\mathrm{FC}$ 
The results show that the undergraduates still don't have much exposure to external earnings other than scholarships, loans, and allowances from parent and others but if there are ample part-time job opportunities for them, it will influence them to have more savings. The undergraduates may gain much financial exposure with parent and relatives' interaction, peer intervention, parent and teacher influence, parent and others input and knowledge and guidance. The factors which can be categorised as futuristic prospects are attitude, future consumption, future wealth, access to financial services, sacrifice current consumption, satisfaction, and selfcontrol. Even though undergraduates get more exposure working with peers and parents and teachers, but more peer intervention and parent and teacher influence will negatively affect the motivation and willingness. Therefore, undergraduates need to be cautious about the effect of both parties to motivation and willingness to saving. During the period of the university, they are mostly out of touch with their parent but more connected to their peers means that more peer cooperation tends to spend more and severely affected to motivation and willingness to save.

It is required to establish sustainable saving practices to improve the savings of undergraduates. Also, it is recommended allowing individual to have some part time jobs for their upkeep during university undergraduate period other than the allowances and scholarships or loans. Policy makers are responsible for designing and implementing such policies to meet important goals for the betterment of the person and the country. However, to design and implement policies a proper understanding of the society's perspective on savings is required which could help to establish sustainable saving practices among individuals. Therefore, all institutions are required to evaluate their existing savings strategies to introduce a new set of strategies to establish long-term savings goals in the country to resolve the burning issue of non-availability of capital in the country without looking to maximise their profit on short-term oriented goals.

\section{References}

[1] Adrian Furnham, A., (1999). The saving and spending habits of young people, Journal of Economic Psychology, 20 (1999) 677 \pm 697 , PII: S016 - 4870 (99) 00030-6, www.elsevier.com/locate/joep (Access date: $18^{\text {th }}$ June 2016).

[2] Agrawal, P., Sahoo, P., Dash, R.K., (2009). Savings behaviour in South Asia, Journal of Policy Modeling, Society for Policy Modeling, 31 (2009) 208-224, www.sciencedirect.com, doi:10.1016/j.jpolmod.2008.11.002

[3] Alwi, S., Hashim, I. Z. A., Sharook Ali, M. S., u.d., Factors Affecting Savings Habits within Millennials in Malaysia: Case Study on Students of Taylor's University, Proceedings of the
Fourth Asia-Pacific Conference on Global Business, Economics, Finance and Social Sciences, ISBN - 978-1-63415762-9, Paper ID: KL539, www.globalbizresearch.org

[4] Ashraf, N., Gons, N., Karlan, D.S., Yin, W., (2003). A Review of Commitment Savings Products in Developing Countries, Harvard University, Development Innovations, and Princeton University.

[5] Bernheim, D. B., Garrett, D.M., and Maki, D. M., (2001). Education and saving: The long-term effects of high school financial curriculum mandates. Journal of Public Economics, 80 (3), 435-465.

[6] Bucciol, A., Veronesi, M., (2013). Teaching Children to Save and Lifetime Savings: What Is the Best Strategy? Working Paper Series Department of Economics, University of Verona, ISSN: 2036-2919 (paper), 2036-4679 (online)

[7] Central Bank of Sri Lanka, (2010-15). Annual Reports, Central Bank of Sri Lanka, P.O. Box 590, Colombo 01, Sri Lanka.

[8] Central Bank of Sri Lanka, (2016). Sri Lanka SocioEconomic Data- 2016 Vol. XXXIX, Central Bank of Sri Lanka, P.O. Box 590, Colombo 01, Sri Lanka.

[9] Elliot III, W., Sherraden, M. S., Johnson L. and Guo, B., (2009). Young Children's perceptions of college and savings; potential role of child development accounts: Centre for social development, CSD working papers No.09-53, Washington University, St. Lovis.

[10] Elser, L., Hannig, A., Eschborn, W. S., (1999). Comparative Analysis of Savings Mobilization Strategies, CGAP Working Group on Savings Mobilization, Consultative Group to Assist the Poorest.

[11] Feldstein, M., (1996). Social Security and Savings: New Time Series Evidence, National Tax Journal 49, 151-164.

[12] Floro, M. S. and Seguino, S., (2002). Gender Effects on Aggregate Saving, Policy Research Report on Gender and Development, Working Paper Series No. 23, The World Bank, Development Research Group/Poverty Reduction and Economic Management Network

[13] Gedela, S. P. R., (2012). Determinants of Saving Behaviour in Rural and Tribal Households (An Empirical analysis of Visakhapatnam District), A Quarterly DoubleBlind Peer Reviewed Refereed Open Access International eJournal - Included in the International Serial Directories Indexed and Listed at: Ulrich's Periodicals Directory (C), U.S.A., Open J-Gage, India, Cabell's Directories of Publishing Opportunities, U.S.A. International Journal of Research in Social Sciences http://www.ijmra.us, IJRSS, Volume 2, Issue 3, ISSU: 2249-2496

[14] Grossbard S. A., Pereira, A. M., (2010). Will Women Save more than Men? A Theoretical Model of Savings and Marriage CESifo Working Paper No. 3146. 
[15] Gunatilake M. M., (2016). 'Precautionary Savings and Social Safety Net: An Empirical Study on Rural Households in Sri Lanka', International Journal of Research in Social Sciences, Vol.6 (10), PP: 515-523.

[16] Hailesellasie, A., Abera, N. Baye, G., (2013). Assessment of Saving Culture among Households in Ethiopia, Journal of Economics and Sustainable Development, Vol.4, No.15, ISSN 2222-1700 (Paper) ISSN 2222-2855 (Online)

[17] Hendricks, L., Chidiac, S., (2011). Village Savings and Loans: A Pathway to Financial Inclusion for Africa's Poorest Households, Commissioned Workshop Paper,2011 Global Microcredit Summit

[18] Hogarth, J., Chris A., and Jinkook L., (2004). "Why Don't Households Have a Checking Account?" The Journal of Consumer Affairs, 38: 1-34.

[19] Jupp, B., u.d., Saving Sense: A new approach to encourage saving, Demos, United Kingdom, www.demos.co.uk

[20] Kempson, E., McKay S., Collard, S., (2005). Incentives to save: Encouraging saving among low-income households, Final report on the Saving Gateway pilot project, Personal Finance Research Centre, University of Bristol.

[21] Koehler, D. J., White, R. J., and John, L. K., (2011). Good intentions, optimistic self-predictions, and missed opportunities, Social Psychological and Personality Science 2(1) $90-96^{\text {a }}$ The Author(s) 2011 Reprints and permission: sagepub.com/journalsPermissions.nav, DOI: 10.1177/1948550 $610375722 \mathrm{http}: / /$ spps.sagepub.com.

[22] Leon, A. K., (2013). Religion and Economic Outcomes Household Savings Behavior in the USA, University of Lüneburg, Working Paper Series in Economics, No. 268-2013, www.leuphana.de/institute/ivwl/publikationen/workingpapers.html, ISSN $1860-5508$.

[23] Mokhlis, S., Salleh, H. S., Mat, N. H. N., (2011). What Do Young Intellectuals Look for in a Bank? An Empirical Analysis of Attribute Importance in Retail Bank Selection Vol. 3, No. 2: E14 Journal of Management Research, ISSN 1941899X doi:10.5296/jmr.v3i2.701.

[24] Oxford Dictionaries, (2017). www.oxforddictionaries. com, (Access date: $18^{\text {th }}$ June 2016).

[25] Peter K. Lunt, P. K., Livingstone, S. M., (1991). Psychological, social and economic determinants of saving: Comparing recurrent and total savings, Journal of Economic Psychology, 12 (1991) 621-641

[26] Ranasinghe, A., Hartog, J., (2002). Free-education in Sri Lanka. Does it eliminate the family effect? Economics of Education Review 21, 623-633.

[27] Salmela-Aro, K., (2010). Personal goals and well-being: How do young people navigate their lives? In S. Shulman and J.-E. Nurmi (Eds.), The role of goals in navigating individual lives during emerging adulthood. New Directions for Child and Adolescent Development, 130, 13-26.
[28] Sherraden, M., and Barr, M. S., (2005). Institutions and inclusion in saving policy. In N. P. Retsinas and E. S. Belsky (Eds.), Building assets, building credit: Creating wealth in lowincome communities (pp. 286-315). Washington, DC: The Brookings Institution.

[29] Sherraden, M., Peters, C., Guo, B., Clancy, M., (2012). Contributions of qualitative research to understanding savings for children and youth, Economics of Education Review 3266 77, SciVerse ScienceDirect Elsevier Ltd., www.elsevier.com/locate/econedurev, http://dx.doi.org/10. 1016/j.econedurev. (Access date: $18^{\text {th }}$ June 2016)

[30] Sherraden, M.S., Johnson, J., Elliott III, W., Porterfield, S., Rainford, W., (2006), School-based children's saving accounts for college: The I Can Save program, Children and Youth Services Review, 29 (2007) 294-312, www.elsevier.com/locate/childyouth, (Access date: $18^{\text {th }}$ June 2016)

[31] Taye, A. Y., (2017). The Saving-Inflation Puzzle: Explaining their Relationship in Ethiopia, Journal Of Humanities And Social Science (IOSR-JHSS) Volume 22, Issue 2, Ver. V (Feb. 2017) PP 74-81 e-ISSN: 2279-0837, pISSN: 2279-0845. www.iosrjournals.org DOI: 10.9790/08372202057481 (Access date: $18^{\text {th }}$ June 2016)

[32] Thung, C. M., Kai, C. Y., Nie, F. S., W., Chiun. L., and Tsen, T. C., (2012). Determinants of saving behaviour among the university students in Malaysia. (Bachelor Thesis), Universitu Tunku Abdul Rahman, Kampar

[33] Tuvesson, J., Yu, S., (2011). Student saving, does it exist? A study of students' saving behavior, attitude towards saving and motivation to save, Degree Project, Umeå School of Business.

[34] Warneryd, K. E., (1989). On the psychology of savingsan essay on economic behavior: Journal of Economic Psychology 10 (1989) 515-514, North Holland. 